\author{
G. Ward \\ University of Oxford, \\ Oxford, England. \\ Professor \\ Extraordinarius \\ University of \\ Stellenbosch, \\ South Africa \\ graham.ward@ \\ theology.ox.ac.uk
}

DOI: http://dx.doi.

org/10.18820/23099089/

actat.v37i1S.1

ISSN 1015-8758 (Print)

ISSN 2309-9089 (Online)

Acta Theologica 2017

Suppl 25:29-42

(C) UV/UFS

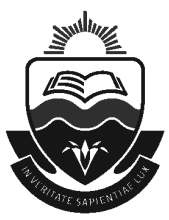

\section{RADICAL ORTHODOXY: ITS ECUMENICAL VISION}

\section{ABSTRACT}

The first book in the Series Radical Orthodoxy (RO) was not meant to be programmatic or set out to change the direction of modern theology. There are certain shared sensibilities among its authors and, principally, an ecumenical vision. This article sketches the nature of that ecumenical vision that begins with the way in which secularism has enabled Christians to look beyond their own denominational borders and even share resources. This is bottom-up ecumenism nurtured by multiple belonging and a global understanding of Christianities that has helped "de-colonize" theology and rethink political theology. RO, it is argued, can be a resource for the South African de-colonization of Christian theology. In its critiques of modernity and secular reasoning, RO points the way towards doing theology in, through and beyond traditional and disciplinary boundaries - but South Africa has to make it its own.

It is now over twenty years since John Milbank, Catherine Pickstock and I organised a colloquium at Peterhouse in Cambridge that became the basis for that collection of essays published as Radical Orthodoxy: A new theology. I remain surprised that, when critics and fans alike characterise Radical Orthodoxy (RO), they point to its origins in John's book Theology and social theory, actually published eight or so years earlier than the collection that initiated the Series published by Routledge. True, John had written earlier about something he called "new orthodoxy" and this was raised and dismissed as a title for the Series when John, Catherine and I sat down to thrash out a name for the number of theological studies we wished to commission. There is, after all, something oxymoronic about "new orthodoxy". Adrian, from Routledge, agreed - but along different lines. For Adrian, the name simply was not eye-catching and radical enough. Then, 
hey presto, the name for the book Series emerged - serendipitously. True also, John's earlier book had laid down a polemical challenge to secularism and its dominance as a methodological assumption in the social and human sciences. That first collection of essays did indeed carry that challenge forward, expressly taking discursive scenes (desire, the body, the city, and so on) that were then viewed theologically. But the notion that the Introduction to that first volume in the Series was programmatic for a new "movement" in theology still surprises me. I speak with respect to the Series: I do not hold the view that RO has a programme or that it can be identified as a specific theological project. Its subsequent history and development is another matter. However, other than organising and attending what became a succession of biannual conferences (in Oxford, Nottingham, Rome, Grenada, Krakow, and Oxford again), my own work (though identified as part of $\mathrm{RO}$ as an ongoing project) has played hardly any part. There is, no doubt at all, a "shared sensibility" (Ward 2013:179) - emphases on "participation" and sacramentalism, principally; a critique of both secularism and the hegemony of Enlightenment reason; an attention to the mythic, the poetic and the materiality of language; the impact of twentieth-century French schools in theology and philosophy, and a concern with the political. But many, if not all of those aspects of that "shared sensibility" are shared with other theologians such as Rowan Williams.

What has deeply impressed me about the reception of RO, above and beyond what the editors of that book series envisaged, is the ecumenical nature of its impact. This certainly was unforeseen and came at a time when top-down approaches to ecumenism had its funding greatly reduced (the World Council of Churches) or had stalled (the Anglican-Roman Catholic dialogue that rumbles along, but continually comes up against the Anglican ordination of women). Yet, undoubtedly, RO, which is liberal with respect to its support for women's ordination and the authenticity of homosexual relations, tapped into a groundswell of ecumenical sensitivities. I am continually astonished at the variety of ecclesial backgrounds of its supporters, given that the three editors of the Series are Anglicans (of the High Church tradition). Somehow RO announces or defines an ecumenical vision that resonates with evangelicals from the Emerging Church, Lutherans, Calvinists, Methodists, Congregationalists, Baptists, Roman Catholics and those committed to Eastern Orthodoxy. And it would not come as a shock, twenty years into the future, that this ecumenical vision (issuing from no programme at all that I am aware of) is RO's lasting legacy. 
Prior to outlining what I perceive as the nature of that ecumenical vision, let me first sketch some of the facts supporting RO's ecumenical outreach, beginning with what occurred subsequent to the launch of the Series in 1998. Within a few months of the publication of that first volume, the papers of a conference held in London were eventually published under the editorship of Laurence Hemming (2000) in the Heythrop Studies in Contemporary Philosophy, Religion and Theology: Radical Orthodoxy? - A Catholic enquiry. The Catholic there is Roman Catholic, and the discussion with Roman Catholics has continued for a number of years (right up to the active support of several Papal Nuncios, Bishops, Cardinals and some papal interaction with Benedict XVI). Of course, a number of Roman Catholic voices are represented in that first volume - Gerard Loughlin, William Cavanaugh, John Montag, Frederick Bauerschmit, for example, with Michael Hanby who later became a Catholic. Other Roman Catholics such as Tracey Rowland contributed volumes to the Series when it was established. In part, the inclusion of Roman Catholic voices was a conscious act made by the editors. After all, they were and are friends. But we were also wishing to reach out to theological voices we recognised as sharing a common sensibility. There were no pre-decided denominational boundaries - the sensibilities were theological and crossed ecclesial frontiers. The Series was open to all those working in Christian theology philosophically, whatever their confessional allegiance.

One of those people was Jamie Smith, from Calvin College in the United States of America (US), who organised the 2002 conference on RO and the Reformed Tradition, editing the volume of essays that appeared in 2005. ${ }^{1} \mathrm{John}$ and I both attended that conference, where Calvinists bent over backwards to proclaim their sacramental allegiances. Finally, through the organisational talents of Adrian Pabst and Christopher Schneider, a conference was held in Cambridge that brought together RO and Eastern Orthodoxy in 2007. The papers of that conference were edited and published in 2009. ${ }^{2}$

To these encounters, coming from very distinctive denominational outlooks, I would add the number of people from the Emerging Church movement in the US, who have regularly attended the RO conferences, and several from South African churches who organised this present conference. Some of these people from an evangelical background have sought advice on how to incorporate a sacramental realism, say, or aspects of Catholic (Anglo or Roman) liturgy into their operations. Some of them have studied with John and Simon Oliver through a long-distance

1 See Smith \& Olthuis (2005).

2 See Pabst \& Schneider (2009). 
course run for several years by the Department of Theology and Religious Studies at the University of Nottingham.

There have, of course, been a number of volumes from other members of these ecclesial traditions (and from the Anglican church) who have been highly critical of RO. If I do not discuss these, it is not that they have nothing to contribute theologically to the ecumenical debates. Indeed, they have. But what I am outlining, in this instance, is the range of ecumenical responses, whether positive, negative or critically engaging. It is partly this broad range of theological responses that prompts my present reflections. What do these traditions find in RO that they wish to engage with, positively, negatively and critically? What is appealing to them?

Sociologically, since at least the 1960s, the main-line traditions of Christian theology have not been holding up against the swell of consumer secularism. Secularism itself is not necessarily the main villain, in this instance. Commitment to institutions in the voluntary sector, such as trade unions and political parties, have seen similar, if not worse, declines in membership. ${ }^{3}$ The trends, as Charles Taylor has outlined in several books, ${ }^{4}$ have been towards DIY spirituality and eclectic choosing among products in the religious market, both in line with, and advancing lifestyle-centred hyper-individualism. What has emerged from this is twofold. First, learning from across the fence. That is, in Britain, traditions have been aware that a spiritual hunger still exists and, in order to tap into it, have scrutinised other traditions or newly emerging ones to find out what they can incorporate. More recently - and wonderfully - we have seen different traditions coming together to share resources! Protestants have faced two different directions, in this instance: the rise of charismatic evangelicalism (which began in the late 1960s with the Elim Pentecostals spawning a number of housechurches) and a return to traditional, conservative, but deeply sacramental pieties. This divide, along with the fact that there were a number, who were now joining the church, who had no catechetical background and no sense of a confessional tradition, led to any number of hybridisations. What have developed, with the critical tide against secularism that began to rise in the $1990 \mathrm{~s},{ }^{5}$ are forms of multiple belonging, where a series of churches might be attended with very different liturgical and doctrinal emphases. But, nowadays, there are few among the Lutheran, Methodists, Congregationalists, Baptists and Anglicans who would consider the founding articles of the faith and confessions upon which the Reformation founded those traditions.

3 See Ward (2016), especially the chapter "The myth of secularism".

4 See, most notably, Taylor (2007).

5 See Ward (2009). 
The Catholic Church, following Vatican II, has also become more diverse - with Tridentine Masses in Latin held here and charismatic renewals there. Vatican II itself incorporated learning from across the fence. It produced documents with regard to other Christian denominations and even other faiths, and it gave increasing emphasis to preaching and the Bible - the mainstays of the Protestant Reformation. Currently, the Orthodox Church is in something of a crisis. They identified themselves as a diaspora church, and certainly not as a conversion church. But it is now awakening to a consciousness of its siloed identity, even self-determined ghettoisation particularly in the US, but also in South Africa - and wanting to enter wider cultural debates about science and faith, for example, and the complexity of overlapping jurisdictions. In the past, the tradition was handed down through families, priests and confessors. At present, they are faced with people who come to them with hardly any or no understanding of what Orthodoxy is. The tradition is changing, being forced to change, and the people who come to them are often refugees from other Christian churches with which they have become disenchanted. In the US, there are any number of second-generation evangelicals seeking depth, mystery, and historical roots. Christians find the emphasis on the present and the Spirit in the present too shallow to resonate with their experience of life.

So there is then, and has been throughout the turn to the post-secular, much more fluidity about the nature of belonging and the nature of Christian belief. This is what I mean by an ecumenism that is bubbling up from below - totally out of sync with, and probably not even aware of the top-level ecumenical forums that continue to judder along. At the grass roots, there is a liquid movement, as people choose their traditions rather than having been born into, and socialised by them. People are moving more across and even blending traditions.

Secondly, Christianity in the west has been increasingly exposed to the variety of world Christianities, and the way in which they have incorporated local or national cultural inflections. Viewed globally, Christianity is recognised as not at all homogeneous, and its western variety is no longer dominant. Post-colonialism has had good effect, in this instance, and I would suggest that South Africa is in the vanguard of new and expressive decolonised theologies. South Africa's resistance of what has been called "westoxification" had long and strong roots in Xhosa theologians who learnt from the missionaries and were converted by them. They began to forge Christian theologies that were Black and indigenous. In some ways, I sense that the interest, at the moment, in decolonising Christian theology in the South African academy is as much to do with discovering and teaching these older Black theologies as realising that they do not 
need to be forever turning to theological faculties and divinity schools in Germany, the US and the United Kingdom (UK) for emulation and approval. Place matters, languages matter, and local cultures (never purely free from previous enculturations) matter. If Christianity is to speak as a living faith, then it must resonate with the life experiences of its particular peoples in their very diverse particular contexts. ${ }^{6}$

Now, what has all this got to do with the ecumenical vision within RO? I opine that, since the publication of the Series and perhaps prior to its publication (and the reason why it has had the wider attention it has had), RO has been viewed as a resource for these new pietistic trends. Anglicanism has always been broad in what it has been able to accommodate and I recall an early conversation with John Milbank about the ecumenical possibilities within Anglicanism that could be shared with other traditions. RO itself has drawn resources for its own work from across the traditions and it has spoken into the western cultures that fostered them. Let me expand on that.

The theology that constitutes the "shared sensibility" of RO - and no one person represents that sensibility, each expanding and drawing in new affiliations that have broadened it - embraces a wide range of traditions that make up the single Christian tradition. For some (I would include myself), the Bible and its interpretation have been important. For some, the Augustinianism that fed both early Protestantism (Luther and Melanchthon, for example) and, in the twentieth century, Nouvelle Théologie, is a source for new theological appropriations - along with the Platonism that inspired Augustine. This Augustinianism, supplemented by the medieval traditions of the Victorines and Aquinas developed philosophical and theological understandings of "realist" rather than "nominalist" world views. Meanwhile, many of the writers in the RO Series were keenly and critically taking on French post-structuralism and the Anglo-American analytical approaches to language and discourse. This led to a critical rethinking of the historical trajectory of modernity, its philosophical alliance with nominalism, and its developments into late capitalism and globalisation; and so to the politics of desire driving economics. I will say more about that in a moment, because it is key to where RO is situated and situates itself. Finally, several in RO have been profoundly impacted by their education in Patristics and have sought reappropriations of apophasis, Logos (rather than reductive historicist) Christologies that relate Christ to a doctrine of creation, an aesthetic and analogical world view, and a Trinitarian metaphysics. In a sense, there is something in this instance,

6 I have said more about this in my "Decolonizing Theology in South Africa", the Steve de Gruchy Lecture (2017), Cape Town. 
whatever the Christian tradition you come from. But, in this way, RO has pointed the way towards doing theology in, through and beyond traditional and disciplinary boundaries. As mentioned earlier, I am not sure that it was conscious of being ecumenical, but many of the theologians espousing RO sensibilities (and doctoral students being supervised by those with RO sensibilities) have practised an ecumenism in their own attempts to rework the tradition for a contemporary proclamation of the gospel.

This appeal to the whole of the Christian tradition and this speaking from a broad church basis that neither emphasised nor extolled a particular tradition has to be viewed alongside a further characteristic of RO theology: its radical critique of modernity and secular reasoning. This critique has furnished a number of critics with ammunition for attack along the lines of "nostalgia" and a desire to return to the "Christendom" of the Middle Ages. Admittedly, genealogical narratives of decline can be found in some of the theologians of Nouvelle Théologie, that have been taken up by philosophers such as Alasdair Maclntyre, social theorists such as Charles Taylor, and historians such as Eamon Duffy. These narratives often place Aquinas as some theological highpoint and view modernity as corruptions of the Augustinian tradition, in particular. John Milbank's Theology and Social Theory, ending on a re-evaluation of Augustine's City of God and an ontology of peace that could counterpose modernity's nominalist nihilism, might be, and has been read in terms of this narrative of decline - a decline, it has to be said, initiated historically from within theological enquiry. ${ }^{7}$ But, to my mind, RO shows a variety of approaches to its critiques of modernity and secular reasoning, and the end of all these approaches is a theological articulation and a sociocultural preoccupation with where we are now. They are not acts of nostalgia. Late capitalism, liberalist humanism (not quite so liberal or humanitarian when transplanted to the colonies) and the urban cultures of postmodernity all come from somewhere. To understand them and why they are failing to provide us with the utopian dreams of enlightenment and universal flourishing modernity espoused, genealogies of their dissemination are necessary. RO has been at the forefront of offering such theological genealogies that we might engage and develop deeper and better theologies that make sense of the Christian faith as it is lived and experienced at present. Especially coming to Africa - carved up into various European ownerships in Berlin in 1884 - the history of colonialism and the struggles against it are more than sufficient testimony to a profound association of modernity with what Foucault called "biopolitics" and Mbembe more accurately described as "necropolitics" (Mbembe 2003:11). Christian theology, in terms of both its

$7 \quad$ See Buckley (1990). 
specific missionary activities and its more general mandate for universal salvation, is in the thick of those politics. RO's critiques of modernity and secular reasoning, bringing to light their overwhelming failures, are part of a concern with the present and the need to get beyond the ideological hegemonies that still operate in that present. To my mind, then, RO does not fetishise some medieval past or the medievalism of the arts and crafts movement. It is inspired by the theology at work in these historical sites.

RO's critiques of modernity and secular reasoning also have to be placed in a theological and historical context. In the 1990s, theology was conducted in two main-line directions. We will discount the "death of God theologians", whose work, on the whole, was over by that time and viewed as the product of well-heeled academics. Liberation theology had also entered a kind of lull, partly because certain political situations had changed in Latin America and South Africa, and partly because it was splintering internally as it was adapted to more western trends in feminist and gay liberation movements, and the rise of public theology. The two main-line trends were correlationism and neo-conservatism. The more liberal wings of liberation theology allied themselves with correlationism. Neither of these trends could enter into the debates about postmodernism or advanced secularism - that is, a secularism flourishing on the basis of rampant consumer capitalism and being enshrined in government policies such as laicité.

Both theological trends were expressions of modernity: correlationism embraced it; neo-conservativism shunned it and developed theologies that effectively were sectarian in their ecclesiologies (whether inspired by von Balthasar or Barth). In his autobiography, Hauerwas (2010) admits that his conception of the church as a citadel against liberal American culture was sectarian. Correlationism took one of two routes: one towards panentheism and process (for example, Gordon Kaufman and Catherine Keller) and the other towards a milky mysticism that could be either pantheism or even atheism (for example, Don Cupitt).

In the thick of these two main-line trends were a number of theologians who were wishing to speak from faith to the cultures in which they were embedded in ways that might be transformative. That is, they wished to uphold the tradition of the faith in a confessional manner, while engaging with the world, its interests, its fashions, and its emphases. These theologians found a resource and, in some instances (such as Rowan Williams), a support in RO. They might be critical of the resource and use it as a sounding board (Charles Taylor, for example, in the last part of his volume $A$ Secular Age), but they sensed what was being attempted. These people might be what I called "burnt-out" or second-generation 
evangelicals in Pasadena, who had discovered television, pop music, internet freedoms, videos, and literature. They might be nuns in Australia who, though liberated through the proceedings of Vatican II and its call to be the church for the world, were seeking a robust theological basis for that work. They might be Anglicans appalled by the Sea of Faith liquidation of their beliefs, but equally appalled by Charismatic congregationalism. What RO provided in this context, as ecumenical resources, was fivefold.

First, as mentioned earlier, there are the genealogies of modernity. RO has characteristically been concerned with history and the question as to how did we arrive at where we are. How did we arrive theologically at the impasse of correlationism and neo-conservatism? To move forward, we needed to understand philosophical and cultural trajectories from the past, how they still haunted the present, and how they distorted what was handed on (the tradition) in ways that were unhelpful and led to a certain bankruptcy when it came to handling contemporary culture. Hence, the appeal was directed to the figures important to the Orthodox Greek tradition (Nyssa, Maximus, Damascene) and to the figures important to the Roman Catholic tradition (Augustine, the Victorines, Aquinas). This appeal to the older Christian tradition, pioneered by de Lubac, Congar and Chenu, brought (as mentioned earlier) the criticism of "nostalgia". But the intention was always to look squarely at the present, and try and forge a future for the Christian faith that reunited us with a past, in which certain things had been forgotten and needed to be restored, if a better theology might be articulated.

This brings me to the second ecumenical resource RO sought to develop: a critical engagement with postmodern culture. Its construction of genealogies was very much the employment of a postmodern tool forged by the likes of Foucault, Baudrillard and Deleuze out of a nihilistic Nietzschean fervour raging against the conservative militarism of post1968 France. Many of these poststructural voices were employing theological tropes culled from a Christian imaginary. They explored terrains that had been the province of theology, but had nothing to do with the church: angels (Michel Serres), the eucharist (Jean-Luc Nancy), the cross (Kristeva), confession (Foucault), the divine (Irigaray, Levinas), the apophatic (Derrida), and so on. They offered an explicit invitation for theologians to engage with them, the cultural scenes they were exploring, the social and political critiques they were forging, and the metaphysics of the ideologies of modernity they were unmasking. Jean-Luc Marion was one of the first to take up this challenge, and Michel de Certeau before him. But many of their works were not translated. RO not only took up these debates in English; their projects acted as a conduit for many of these 
French voices to be heard in theological circles throughout the Englishspeaking world. Theology has always been an interdisciplinary project. This is necessary, because theology has no proper object of its study God is not available to us, as the economy is to economists, politics for politics scientists, human beings for anthropologists, or sexual mores for gender studies. RO exploited this interdisciplinarity to create a different kind of theological discourse (comfortable to certain correlationists, but even now highly uncomfortable for neo-conservatives).

The third emphasis that RO sought to advance that became an ecumenical resource across the different traditions was a concern with the embodied and the material. It took up many of the poststructural antipathies to dualism, while not wishing to capitulate to a Deleuzian plane of immanence and a Heraclitan flux. Since both of these philosophies capitulate to a univocity of being, they were to be countered by a crucial emphasis on participation and analogy, drawing attention to analogy as a mode of understanding creation's relationship with the Creator rather than simply a rhetorical trope. This transfigured the divisions between nature and grace, philosophy and theology, immanence and transcendence, as well as the concept of "revelation".

Following Kant (and taking Barth as their champion), conservative theologians adopted the notion of "revelation" as some vertical breaking in point of the pure. This understanding of "revelation" offered them the possibility for a new foundationalism as distinct from the anthropological foundationalism of liberal theologies. But it did so by espousing an equivocity of being, a radical ontological dualism. Pursuing a line of antifoundationalism in continental philosophy, but developing it in a theological direction inspired by the theological turn in phenomenology (following Merleau-Ponty), RO advocated a different understanding of revelation that accorded with more traditional understandings of the relationship between faith and reason. In doing so, it also exposed the fallaciousness of this Kantian turn for theology. This is where RO developed a theology of participation that accepted and welcomed mediation, all the way down, as a principle of the Incarnation itself. It called for a radical hermeneutics that recognised language (and culture as the expressive expansion of human beings as a symbolic species) as key. Put simply: made in the image of God, we are image-makers; we are creatures endowed with the creative capacity to imagine, because we are hidden in God's own imagining. There are no foundations: the mystery and depths of the Godhead reflected in the mystery and depth of being human. In a memorable phrase of Milbank's: we participate in "the divine linguistic being" (Milbank 1997:2). This launched the linguistic turn in contemporary philosophy in a distinctly theological 
direction - in the direction of a new Christological understanding of the communicatio idiomatorum.

The work on constructing genealogies of modernity went hand in hand with exploring changes in the understanding of the secular. For the secular was never viewed as a distinct and self-authenticating domain. I would say that RO offered a fourth ecumenical resource for Christian theologies that cannot be separated from the attention to language, communication, story-telling and myth-making. It asked not merely what are the metaphors we live by, ${ }^{8}$ but also what are the narratives and myths whereby we both make sense of our world and seek to control it? RO emerged just as the secularisation thesis was in tatters, following the unprecedented public visibility of religion with the rise of political Islam (dating from the oil crisis and the Iranian revolution in the 1970s). The secular world view was increasingly being regarded as a form of state-sponsored ideology - particularly in France. RO asked: How was this story of the secular composed and why was it believed in? All our world views are narrations, but the secular came to be understood as some default natural condition, with Europe leading the way. Secularisation was an historical project, even a destiny. The Church saw it as a threat (the Roman Catholic rejection of modernism in the $19^{\text {th }}$ century, for example), or an opportunity (had not Christianity always demythologised the idolatrous world?), or an irrelevance (the Kingdom was not of this world anyway). But, increasingly, the Church was viewing itself as a victim of secularism. It had internalised and tried to appease the force of secularism.

$\mathrm{RO}$ worked upon another narration, attempting to change the cultural imaginary, challenging the assumptions of secular reason and what Charles Taylor called "exclusive humanism". That was one of the main intentions behind the discussions and colloquium that led to the first volume of essays in the Series: they take up some of the sites in which secular modernity had heavily invested (the body, the city, language, desire, knowledge) and present a theological account that refigured how these sites might be imagined in ways that brought Christian flourishing.

$\mathrm{RO}$ was always political and consciously so. As such (this is the fifth and final resource RO offered), RO developed a new political theology. ${ }^{9}$ Some have criticised its over-optimism, its Platonic idealism and its abstract intellectualism. I see no difficulty with such criticism. Theologians are not gods. We put out there our convictions and arguments. We should expect to be challenged and held to account, particularly by other theologians

8 See Lakoff \& Johnson (1980).

9 See Davis et al. (2005). 
and those concerned for the future of the Church. Some voices in the RO Series are more explicitly political than others - and have been engaged in political affairs whether championing Red Toryism or Blue Labour. ${ }^{10} \mathrm{~A}$ certain qualified socialism can be scented in many of its projects. But its politics issue from its theological, not necessarily party commitments; for its concern lies with the common good, the public good, the cultivation of virtue and the Christian habits of citizenship that are rooted in belonging. If you like, in this instance, a theology of participation reaches out towards political participation, just as a concern with embodiment and the material as sacramental demand a similar concern for the body politic and the commonwealth. Citizenship has also to be an expression of discipleship. ${ }^{11}$ In its explicitly political posture, I hope RO has offered an ecumenical resource not only for the Church, but also for the societies within which the Church is situated in its cure of souls.

Let me draw to a close. Ecumenism is not universalism, as anyone who has examined the history of the great ecumenical councils knows. Consensus was reached, but not everyone agreed. Deliberations were long and involved subtle theological distinctions. The deliberations are ongoing, as faith continually seeks its understanding. Arguments were weighed carefully and there were more powerful factions and marginalised minorities. So what is new? Conclusions were often terse and phrased in ways that respected a certain generosity of interpretive practice.

There are many good common-sense reasons for churches collaborating at present - not least the better sharing of limited resources. But there are even better theological reasons for ending the contentious confessionalism that has enormously injured the Church's witness to the world. We are not here as the Church for ourselves. We are here for the world we serve. The work of the Church is to do itself out of a job. It is not the Kingdom. Ecumenism is a mark of the character of Christian culture. It is not merely the work of leaders and administrators. It is an aspect of true discipleship. Of all the things, good and less good, to which $\mathrm{RO}$ has given expression, if it has offered, as I have argued, theological resources for the churches to come together, then I am content. For though we are many, we are one in Christ.

As a South African coda: however broad its ecumenical vision, this is what RO cannot do for South African theology. It cannot reflect the textures of the stars - clusters, clouds, nebulae - that you see in this

10 These are projects espoused in Britain by Philip Blond and Maurice Glasman. Philip was very much part of RO in its early stages.

11 See Ward (2009) and, more recently, Milbank \& Pabst (2016). 
hemisphere. It cannot reflect the rejoicing when rain clouds with flashing lightning gather on the horizon of the veld. It cannot, in its English, carry the guttering inflexions of the trekboere or the sound of water and birds in the clicks and vowels of Xhosa. To be in touch with these beauties, to be resonant with these beauties, is what South African theology can do - and, in doing so, it will modulate, in its own key, the emphases in RO upon participation and sacramentality. If RO has any place in the complex histories, linguistics and materialities of South Africa, then that place lies in fostering a theology that is not White, western and, on the whole, male. In doing that, the ecumenical vision is broadened, and so is RO. At that first conference in London on the launch of the Series, I recall a Catholic woman who sat quietly through all the papers and the discussions that followed, and then stood up and said: "In all I have heard, there is nothing new here. Surely this is the Christian gospel." I nodded in total agreement. If $\mathrm{RO}$ is a "new theology", it is only rehearsing theologies we have forgotten in our modern preoccupation with the present and the now. If you in South Africa learn from it - then make it your own; sing and dance it in your way. That would be the greatest gift and testimony to the ecumenical vision of RO and something John, Catherine and I could never do.

\section{BIBLIOGRAPHY}

BUCKLEY, M.J.

1990. At the origins of modern atheism. New Haven, CT: Yale University Press.

Davis, C., Milbank, J. \& Zizek, S. (eds)

2005. Theology and the political: The new debate. Durham, NC: Duke University Press. https://doi.org/10.1215/9780822386490

Hauerwas, M.

2010. Hannah's child: A theologian's memoir. Grand Rapids, MI: Wm B. Eerdmans.

Hemming, L.P. (ED.)

2000. Radical Orthodoxy? - A Catholic enquiry. London: Routledge.

LAKOFF, G. \& JOHNSON, M.

1980. The metaphors we live by. Chicago, ILL: University of Chicago Press.

Mbembe, A.

2003.Necropolitics.Public Culture15(1):11-40.https://doi.org/10.1215/08992363-15-1-11

MiLbanK, J.

1990. Theology and social theory. Oxford:Basil Blackwell Publishers

1997. The word made strange. Oxford: Blackwell. 
Milbank, J. \& Pabst, A.

2016. The politics of virtue: Postliberalism and the human future. London: Rowman \& Littlefield.

Pabst, A. \& Schneider, C. (eds)

2009. Encounter between Eastern Orthodoxy and Radical Orthodoxy: Transfiguring the world through the word. Farnham: Ashgate.

Sмith, J.K.A. \& OLthuis, J. (EDS)

2005. Radical Orthodoxy and the reformed tradition: Creation, covenant, and participation. Grand Rapids, MI: Baker Academic Press.

TAYLOR, C.

2007. A secular age. Cambridge, MA: The Belknap Press of Harvard University Press.

WARD, G.

2009. The politics of discipleship: Becoming post-material citizens. Grand Rapids, MI: Baker Academic Press.

2013. On being radical and hopefully orthodox. In: D.C. Marks (ed.), Shaping a global theological mind (Aldershot: Ashgate), pp. 177-186.

2016. Unbelievable: Why we believe and why we don't. London: I.B. Tauris.

Keywords

Radical orthodoxy

Ecumenical vision

Decolonisation
Trefwoorde

Radikale ortodoksie

Ekumeniese visie

Dekolonisasie 